\title{
THE EFFECT OF VIDEO GAMES ON THE LIFE STYLE OF ADOLESCENTS (OF ADOLESCENTS OF THE SECOND DISTRICT 5 TEHRAN)
}

\author{
Simin Bakhshizadeh \\ Department of Social Communication Sciences, Ardabil Science and Research Branch, Islamic Azad \\ University, Ardabil, Iran \\ Ali Jafari \\ Department of Social Communication Sciences, Ardabil Branch, Islamic Azad University, Ardabil, Iran \\ Jafari.communication@gmail.com
}

\begin{abstract}
The aim of this study was investigating effect of video games on change of life style of adolescence in the second grade of high schools in district 5 of Tehran. Methodology $\mathrm{f}$ this research is applied according to purpose and correlative-surveying according to method. Statistical population of this research is 28348 students in district 5 of Tehran high schools that sample volume was determined 384 by Cochran formula and sample was selected by simple random method and stratified sampling method. Results showed that the highest effect of life style among studied variables is first in apparent coverage $(\beta=0.31)$, second in fashions $(\beta=0.27)$, third spending leisure time $(\beta=0.16)$, and the fourth imitation and modeling $(\beta=0.13)$. The results showed that the second term school district 5 Tehran lifestyle of adolescents' function of dependent variables, or cover appearance, fashion-oriented, leisure time activities and duplication of video games is modeling. Because the two variables influence social relationships and family relationships were eliminated from the equation of video games was not fixed.
\end{abstract}

Keywords: computer games, lifestyle, youth, cover appearance, fashion-oriented

\section{ERGENLERİN YAŞAM ORTAMLARI ÜZERİNE VIDEO OYUNLARININ ETKİSİ (ÍKİNCİ BÖLGE 5 TAHRAN)}

\section{ÖZ}

$\mathrm{Bu}$ çalışmanın amacı, Tahran'ın ilçesinde 5 liselerinin ikinci sınıfta ergenlik yaşam tarzı değişikliği video oyunları etkilerini araştırıyordu. Bu araştırmada f Metodoloji amaç ve yönteme göre bağlaşık-ölçme göre uygulanır. $\mathrm{Bu}$ araştırmanın istatistiksel nüfus basit rasgele örnekleme yöntemi ve tabakalı örnekleme yöntemi ile seçilen örnek hacmi Cochran formülü ve örnek tarafından 384 belirlenmiştir Tahran liselerinin ilçesinde 528348 öğrencidir. Sonuçlar çalışılan değişkenler arasındaki yaşam tarzının en yüksek etki modası ikinci, belirgin kapsama $(\beta=0.31)$ ilk olduğunu göstermiştir $(\beta=0.27)$, üçüncü harcama boş zaman $(\beta=0.16)$ ve dördüncü taklit ve modelleme $(\beta=0.13)$. Sonuçlar bağımlı değişkenler, ya da kapak görünüm, moda odaklı, boş zaman aktiviteleri ve video oyunları çoğaltılması ergenlerin fonksiyonunun ikinci dönem okul bölgesi 5 Tahran yaşam tarzı modelleme olduğunu gösterdi. iki değişken sosyal ilişkiler ve aile ilişkileri video oyunları denkleminden elimine edilmiştir etkileyen çünkü sabit değildi.

Anahtar Kelimeler: bilgisayar oyunları, yaşam tarzı, gençlik, kapak görünümü, moda odaklı 


\section{INTRODUCTION}

Adolescence refers to the area of the child to adulthood joins (Kanjer and Peterson, 1984; quoted by Mansur, 2002). Stanley Hall during this period, "the hurricane, and severe stress" and also during extraordinary ability physical, mental, and emotional considered. A number of leading practitioners and theorists of psychoanalysis teenager knows that the situation where the teen is mentally disturbed (Freud and others, quotes Mason et al, 2005, quoted by Mansur, 2002).

Some psychologists' adolescence and maturity of the credit during the riots, rebellion has been called. By mentioning the word about maturity, it is conceivable that young people are unruly and disruptive, but they seem in this case to internal revolution and foreign physical aspects of puberty and not realize it, because at this stage, changes combination of physiological changes in the behavior of adolescents have difficulty in adaptation and compromise with the environment (Aghamohammadian and Hosseini, 2005).

Lifestyle relatively constant way that a person uses to achieve its goals, the way to achieve life goals. This style of one's childhood; in other words, lifestyle, objective, and quantifiable character after individuals. For this reason, the theory of (lifestyle) Adler, the theory of "personality," he is. First, Alfred Adler (1922) proposed a theory of life, and this concept was later expanded his followers.). Adler followers in detail about the lifestyle, its formation in early childhood, basic attitudes involved in lifestyle, the basic functions of life and they interact with each other talk and it showed in the form of the tree of life. They also value concepts, anthropological, philosophical and built as an integrated whole life portrayed. Lifestyle is the most important factor that everyone adjusts his life accordingly. Accordingly, lifestyle collection of ideas, drawings and samples habitual behavior, desires, and ways of defining social or personal conditions that will determine the specific type reaction. Despite the dramatic expansion of media, it seems, video games that have an important role in leisure time. video games is one of the least expensive ways of spending leisure time, while computer and video games at all hours of the day and can be used at home. Maybe that's why one of the most popular video games as mass media and vital role in the lives of adolescents and young people are filling their leisure time. What more video games in children and adolescents is fascinated, improve the quality of the games, which will shortly become common in Iran and markets toys and audio-visual equipment is out to conquer. Another factor that increased the number of fans of the game, its affordable price for the consumer. Therefore, the main question in this study is that video games are what the school is involved in changing the life style of adolescents second term? What is the effect of video games on adolescents spend leisure time? And social values which make the game more than the other values change put at risk? I will attempt to answer the question of video games in high school teenagers prosperous and non-prosperous district 5 Tehran has been studied and changes and changes in social values to be examined.

The rate of video games with the lifestyle of adolescent's district 5 Tehran there is a significant relationship.

Played video games with physical coverage adolescents between the districts 5 Tehran There is a significant relationship.

The rate of video games and leisure time activities for teenagers district 5 Tehran there is a significant relationship.

Do video games and family ties between the teenagers district 5 Tehran, there is no meaningful relationship.

Do video games and social relations between the teenagers district 5 Tehran, there is no meaningful relationship.

The rate of video games and lifestyle trends among adolescent girls district 5 Tehran there is a significant relationship.

The rate of video games and lifestyle trends there is a significant relationship between adolescent boys district 5 Tehran. 
For the theoretical framework of the present article, we used the following three approaches:

\section{- Theory of Structuration Giddens:}

Giddens Structuration theory of the two positions opposite each other theorists consider them creates. That is the theory on the one hand and theories related to the individual on the other hand, he finds common ground between the two theories, based on a simple idea structuration theory of its own. Everything in public life, of what niche global systems to what is the state of mind of a person in a social action to occur. Skillful execution of deeds means retreats behavior and interaction. In theory structuration and build a social system will connect to each other in time and space and the realm of social science studies that examine social practices across time and space own again, the order (Stones, 2000).

According structuration, the human factor and construction of encapsulation are associated with repeat behaviors, structures hive reproduces by that reproduces the structures of human action, human activity limits their structure. Social structure primarily due to the daily activities of and adherence to rules and structure dates back to those rules lies in such an action (Kraib, 2002)

Giddens clearly emphasizes the importance of social action. (Stone, 2000) exaggerate far-fetched metaphor is sociological imagination increases a theorist. But as we said, Giddens in his writings and ideas of the extreme and exaggerated by the opposition.

1 - The varied social events, in different historical periods and in different ways and change their social practices.

2 - The multiple consequences of various social practices can never be fully pre-designed and controlled. Giddens believes and knows with certainty the behavior, often in the form of reproduction is quite uniform. That can bring surprising results (Stone, 2008).

In computer games to attend, contribute and might have been influenced more in the reproduction means they will be less.

\section{- Social learning theory}

Most video games like other media technologies of the West and today an inseparable part of the lives of our teens has become, since the days of television (video games) in the family active and learning of family members and modeling them upon is observational learning. Bandura to study ways of seeing and imitating human learning is addressed. He has this type of learning are the most important factor in learning and development. Bandura, learning in addition to interest, have the ability to emulate and copy. Social learning is based on observation and imitation, unconsciously in many positive and negative accomplished and productive outcomes, and will follow their pernicious (Parsa, 2004).

\section{- Bourdieu and lifestyle}

One of the fundamental concepts of Bourdieu's sociology concept of "habitus" is open the behavior of distinct principles of distinctive habits are, what's working, and especially the way he is eating a sport that does do it, so systematic, similar cases with different industrial management style the meaning of life and the habit schema uses the same tastes (Bourdieu 2002).

\section{METHODS AND MATERIALS}

The methodology of the survey and survey. The goal of this research, including applied research. The study population consisted of high school students in the district 5 Tehran is, when carrying out this research in public and private schools are studying any student who point at the base of the second period is attending high school in District 5 is the statistical unit. 
The number of students attending high schools in district 5 Tehran 28 thousand and 348 people per year. Of which 13 thousand 374 people and 974 were girls and 14 million boys up. The number of students is enrolled in 102 schools, of which 58 high schools and 44 public secondary school are non-profit. This set 384 as the sample will be selected by Cochran.

$$
n=\frac{28348 \times 1.96^{2} \times 0.5(1-.5)}{28348 \times 0.06^{2}+1.96^{2} \times 0.5(1-.5)}=384
$$

\section{FINDINGS}

Equivalent to $49.4 \%$ of the respondents in terms of gender, 193 were male and $46.8 \%$ female equivalent of 183 people broke up and 8, or 0.2 percent did not respond to questions.

In terms of education equivalent to $32.2 \%$ of the total respondents, 126 years, 146 people, equivalent to 37.3 percent in the second, 75 the third year of 19.2 percent and the number of 19 people have formed the equivalent of 4.9 percent of high school students and 11 is equivalent to 3.2 to have not answered the question.

Of the total number of respondents, 28 people, 16 of 7.2 percent, equivalent to $50.9 \%$ of 17 of 199 patients, $93(23.8 \%)$ of $18,43,19$ and 10 were equivalent to 11 per cent or 2.6 per cent were aged 20 and 11 people 2.8 percent did not answer the question.

Of the total number of respondents, 141 or 36.1 percent fun games, action games 21 percent of the 81 people, 59 people or $15.1 \%$ of strategic games, 52 per cent of 13.3 war games, 10 games, the equivalent of $2.6 \%$ form of violence, 10 people or $2.6 \%$ of the games of the accident and 23 other games have chosen the equivalent of 5.9 percent and a 0.3 percent people have not responded to this question.

Of the total number of respondents, 133 people doing the equivalent of 34 percent by mobile computer game, the number 89 is equivalent to 22.8 percent by Xbox, the PSP by 61 people or $15.6 \%$, equivalent to $13.3 \%$ of 52 patients by computer 24 people, equivalent to 6.1 by iPad, equivalent to 3.1 percent by PlayStation to play 12 of their computer and 2.8 percent of 11 patients did not respond to questions.

The relationship between the rates of video games with the life style of adolescent

Table (1) shows the relationship between the rates of video games with the life style of adolescents

\begin{tabular}{|c|c|c|}
\hline Result & Correlation & Significance level \\
\hline Hypothesis & 0.73 & 0.000 \\
\hline
\end{tabular}

Pearson's test results show that $99 \%$ and less than $1 \%$ error level of meaningful relationship between two variables between the role played video games with physical coverage teenagers district 5 Tehran There is a significant relationship. In this regard, the relationship is a strong positive correlation coefficient is equal to 0.73 . So we can conclude whatever the highlighted computer games and more, the more the life style of adolescents affected.

The relationship between the apparent coverage rates of video games with teenagers

Table (2) shows the relationship between video games does look covered with teenagers

\begin{tabular}{|c|c|c|}
\hline Result & Correlation & Significance level \\
\hline Hypothesis & 0.78 & 0.000 \\
\hline
\end{tabular}


Pearson's test results show that $99 \%$ and less than $1 \%$ error level of meaningful relationship between two variables between the roles played video games with physical coverage teenagers district 5 Tehran there is a significant relationship. In this regard, the relationship is a strong positive correlation coefficient is equal to 0.78 . So we can conclude whatever the highlighted computer games and more, young people in choosing the type of mimic the appearance of the characters in video games.

The relationship between the conduct video games with leisure time activities for teenagers

Table (3) the relationship between the conduct video games with leisure time activities for teenagers

\begin{tabular}{|c|c|c|}
\hline Result & Correlation & Significance level \\
\hline Hypothesis & 0.73 & 0.000 \\
\hline
\end{tabular}

Pearson's test results show that $99 \%$ and less than $1 \%$ error level of meaningful relationship between two variables between the role played video games with leisure time activities for teenagers district 5 Tehran There is a significant relationship. In this regard, the relationship is a strong positive correlation coefficient is equal to 0.73 . So we can conclude whatever the highlighted computer games and more, young people spend more of their leisure time playing video games. The relationship between the conduct video games with family ties teens

Table (4) the relationship between the conduct video games with family ties teens

\begin{tabular}{|c|c|c|}
\hline Result & Correlation & Significance level \\
\hline Hypothesis & -0.024 & 0.654 \\
\hline
\end{tabular}

Pearson's tests results indicate that the role played video games with family relationships between two variables teenagers district 5 Tehran there is no meaningful relationship. In this regard, correlation coefficient equal to -0.024 that the relationship is weak. So it can be concluded in computer games and social relations adolescents there is no significant relationship.

The relationship between the social relations of adolescents does video games

Table (5) the relationship between the social relations of adolescents do video games

\begin{tabular}{|c|c|c|}
\hline Result & Correlation & Significance level \\
\hline Hypothesis & 0.08 & 0.10 \\
\hline
\end{tabular}

Pearson's test results indicate that the role played video games with social relations between the two variables teenagers district 5 Tehran there is no meaningful relationship. In this regard, correlation coefficient equal to 0.08 , relationship is weak. So it can be concluded in computer games and social relations adolescents there is no significant relationship.

The relationship between the computer game and lifestyle trends among girls

Table (6) shows the relationships between the computer game and lifestyle trends among girls

\begin{tabular}{|c|c|c|}
\hline Result & Correlation & Significance level \\
\hline Hypothesis & 0.335 & 0.000 \\
\hline
\end{tabular}

Pearson's test results indicate that the rate of video games and tends to be variable between two teenage girls fashion district 5 Tehran there is a significant relationship. In this regard, the relationship is a strong 
positive correlation coefficient is equal to 0.335 . So we can conclude whatever the highlighted computer games and more, will be more inclined to lifestyle changes among female adolescents.

My hypothesis: the relationship between computer games and lifestyle trends among boys

Table (7) relationship between computer games and lifestyle trends among boys

\begin{tabular}{|c|c|c|}
\hline Result & Correlation & Significance level \\
\hline Hypothesis & 0.177 & 0.01 \\
\hline
\end{tabular}

Pearson's test results indicate that the rate of video games and tends to be variable between two teenage girls fashion district 5 Tehran there is a significant relationship. In this regard, the relationship is positive correlation coefficient of 0.177 . So we can conclude whatever the highlighted computer games and more, will be more inclined to change lifestyle among adolescents. The trend is highlighted in girls than boys.

\section{CONCLUSION}

The results show that the greatest impact on the lifestyles of the studied variables respectively in the first cover appearance $(\beta=0.31)$ second-order fashions $(\beta=0.27)$ third-order recreation $(\beta=0.16)$ and times fourth duplication and modeling $(\beta=0.13)$, respectively. The results showed that the life style of adolescents of high schools in district 5 Tehran second function of dependent variables, or cover appearance, fashion-oriented, leisure time activities and duplication of video games is modeling. Because the two variables influence social relationships and family relationships were eliminated from the equation of video games was not fixed. The results obtained in this study on the effects of video games to imitate, and finally among the young, fashion-oriented, formal wear clothes, how to spend leisure and ... that all these high-intensity proven that video games have a huge impact in this category categories and these categories also indicate that anti-social behavior are exactly consistent with the conclusion that Mrs Sadeghian (2006) in article impact of computers and the internet on children and adolescents, and the result is that Mrs. Maryam Ghatrifi on paper examines the impact of video games on health and academic performance of boys and girls secondary school in his article brought Tehran and video games in addition to anti-social behavior has affected the physical health. And also of Mr. Zare (2009) also in his article titled video games and social skills exactly the same conclusion.

\section{REFERENCE}

Aghamohammadian, HR and Hosseini, SM (2005). "Psychology of puberty and adolescence (developmental psychology 2)", Mashhad: Astan Quds Razavi.

Bourdieu, P (2002). Theory of action: practical reasons and rational choice, translator Morteza man, Tehran: Stencils,

Kraib, Y. (2002). Modern social theory from Parsons to Habermas. Translator Abbas informant. Tehran: Agah publishing.

Mansur, M. (2002). "Genetic Psychology, (mental development from birth to old age)", third edition, Tehran: Publication side.

Parsa, M., (2004). The new field of psychology, Tehran, mission, twentieth edition: 217.

Sadeghian, E., (2006). "The Impact of Computers and the Internet on children", Monthly Media and the Family, the influence of mass media on the bonds of affection in families, taken from the site grow

Stones, R. (2000). Great thinkers sociology. Translation: Mehrdad Mirdamadi. Tehran: Publication center.

Zarei, A. (2009). The relationship between computer games with social skills high school students of Tehran 